\title{
تقويم السياحه الرياضية وتاثيرها على الجذب السياحي بمحافظة الاقصر
}

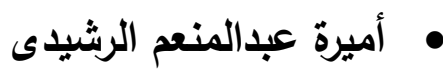

\section{مقدمة ومشكلة البحث :}

السياحة تعتبر ظاهره إنسـانية قديمة،قدم المجتمعات الإنسانية، وقد تطورت

خلال النصف الثاني من القرن الواحد والعشرين تطورا كبيرا، أصبحت ظهاهره عالمية ،لا يستطيع احد إنكارهـا، حيث أثتتت أنها ظـاهره ذات أنتار اقتصـادية، واجتماعيـة، وتقافية،وسياسية وبيئية بعيدة المدى، ولذا فقد تزايد الاهتمام العالمي بهاهبوصفها أكبر الصناعات المولدة للاخل وفر ص العمل، وقاطرة للتتمية الاقتصادية، لما لها من تأثثر

$$
\text { على مختلف القطاعات الاقتصادية. ( (1: . . ) }
$$

فيشير "هباس الحريسي " ( r ب r ) إلى إن السياحة الرياضية من المصـادر

الهامـة التي تستخدمها الدول، في تسويق السياحة إليها، حيث ينوافد المشـاركون في الرياضـات المختلفة، والذين بستمتعون بمشـاهدة أو ممارسـة تلك الأنشطة، مما يؤدى إنى لوجود سياح كثر، وهى تتطلب إنشاء بنية تحتية قوية، على مستوى عالي من التقدم

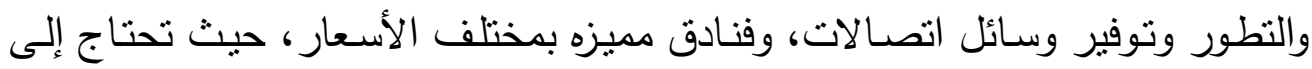

استثمار أموال كبيرة وضخمه لزيادة المقومات السياحية لتلك الدول. ( r : آ )

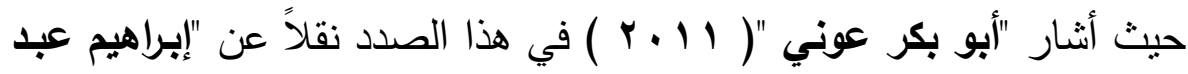

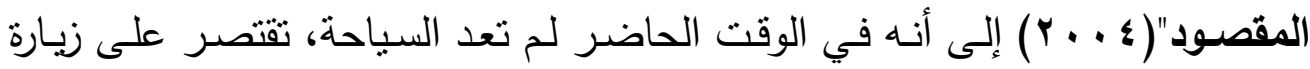
الآثار القديمة التي خلفها الأجداد، لكن بدأ هنالك اتجـاه عالمي جديد لربط السياحة

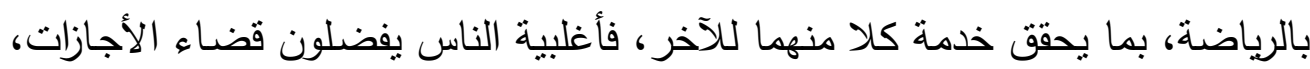
ووقت الفراغ في ممارسة أوجه النشاط الرياضي في الدول المتقدمة.( ب : 0 ( ) 
تعتبر السياحة من الظواهر الاجتماعية التي نشأت منذ أن خلقت الأرض وما

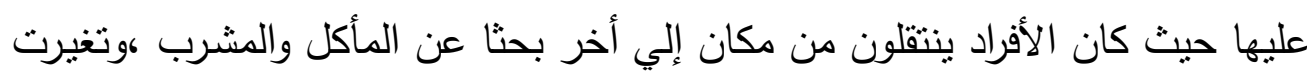
النظرة في العصر الحديث وتطورت وأصبحت السياحة صناعة مركبة من الصناعات الصنات الصرد الهامـة التي تعتمد عليهـا الكثير مـن الدول في تتميـة مواردهـا الماليـة لتحقيق التقدم الاقتصادي والاجتماعي بها ـ ( ع : 1 )

** باحثه دكتوراه بقسم الإدارة الرياضية والترويح - كلية التربية الرياضية - جامعة اسوان. وتتميز مصر بتتوع مواردها السياحية التي تعتمد علي إمكانات تاريخية وثقافية ودينية وجغرافية ،لذا تعتبر السياحة مصدرا هاما من مصادر الدخل القومي المصري كوإدراكا للدور الذي يؤديه هذا القطاع تعمل الدولة علي زيادة عدد الليالي السياحية إلي هي

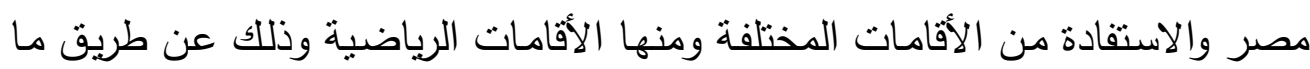
يسمي بالسياحة الرياضية حيث يسعى هذا الاتجاه الحديث إلي تسويث البرامج السياحية

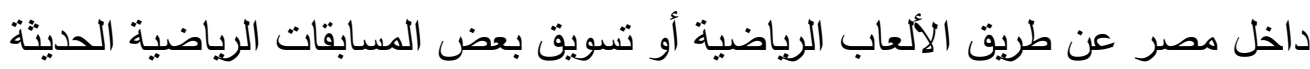
مثل مسابقات الجولف والاسكواش والألواح الثراعية عن طريق السياحة ـ ( ع: 1 ) )

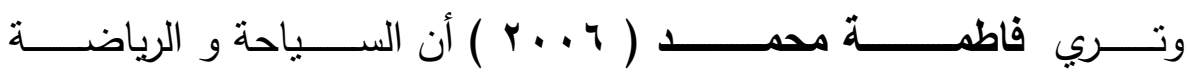

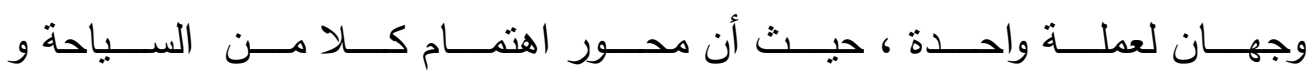

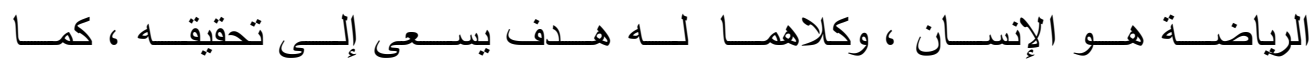

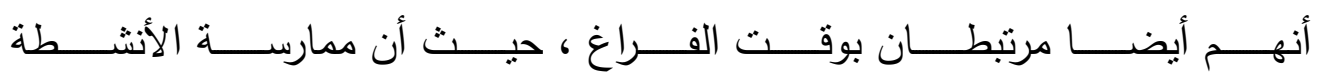

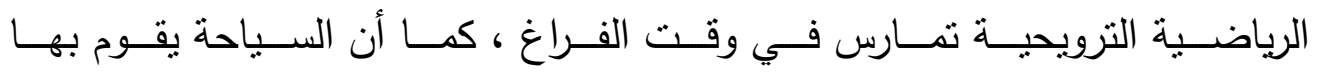

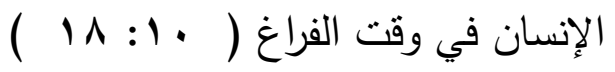




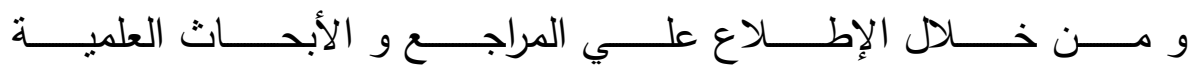

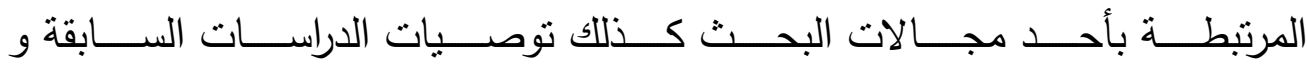

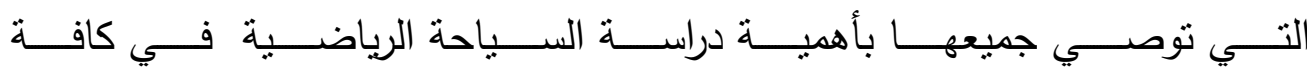

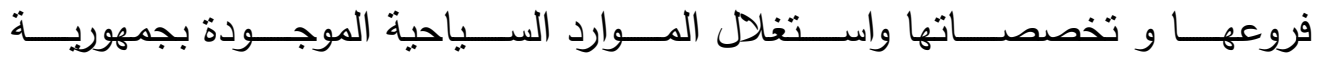

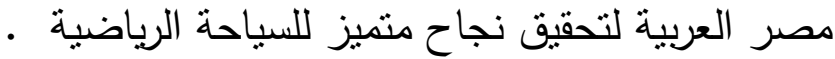

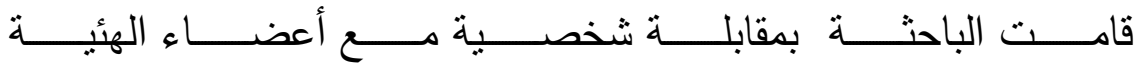

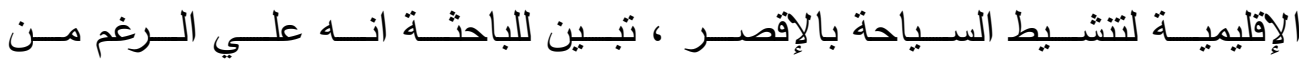

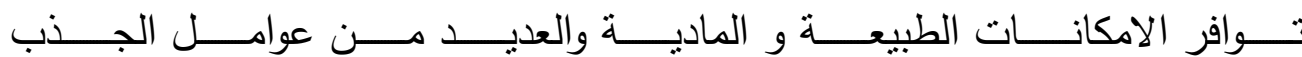

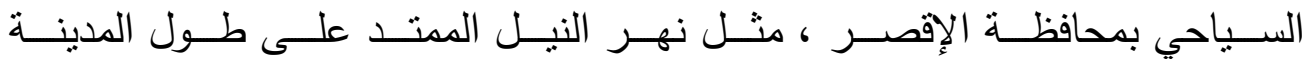

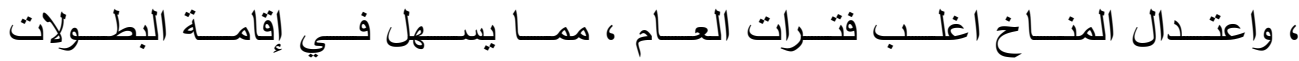

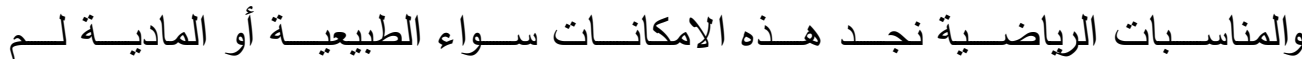

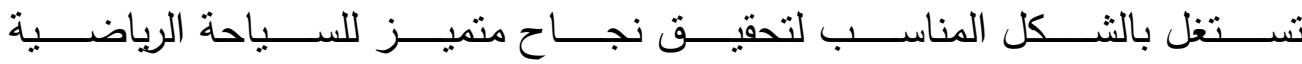

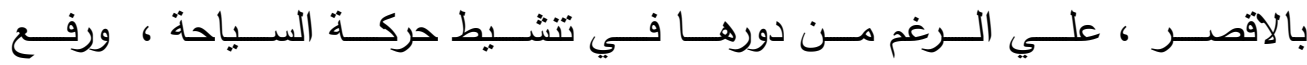

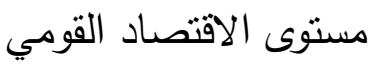

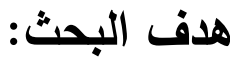

تقويم السياحه الرياضيه وتاثيرها على الجذب السياحى بمحافظة الاقصر وذلك من خلال أهداف السياحة الرياضية بمحافظة الإقصر وتنقسم إلى : - الأهداف العامة للسياحة الرياضية بمحافظة الإقصر . الأهداف الاقتصادية للسياحة الرياضية بمحافظة الإقصر الإجراءات اللازمة لتحقيق أهداف السياحة الرياضية بمحافظة الاقصر . 
تتوافر الإجـراءات الخاصـة بتحقبـق الأهداف الاقتصـادية للسباحة الرياضــة بمحافظـة الإقصر

الامكانات اللازمة لتحقيق أهداف السياحة الرياضية بمحافظة الإقصر وتثقسم إلى : الامكانـات الماديـة اللازمـة أهداف السباحة الرياضية بمحافظــة

$$
\text { الإقصر }
$$

الامكانات البشرية اللازمة أهداف السياحة الرياضية بمحافظة الإقصر

$$
\text { تساؤلات البحث: }
$$

وللوصول إلى تحقيق هدف الدراسة كان لابد من الإجابة على التساؤلات التالية

\section{ا ـ أهداف السياحة الرياضية بمحافظة الإقصر •}

ماهي الأهداف العامة للسياحة الرياضية بمحافظة الإقصر .

ماهي الأهداف الاقتصادية للسياحة الرياضية بمحافظة الإقصر

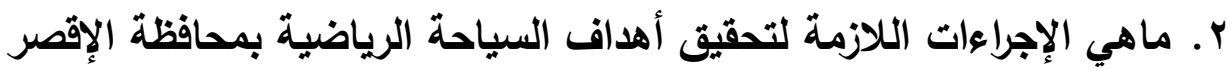

ماهي الإجراءات اللازمة لتحقيق الأهداف الاقتصادية للسياحة

$$
\text { الرياضة بمحافظة الإقصر ؟ الإهر }
$$

ماهي الإجراءات اللازمة لتحقيق الأهداف الاجتماعية للسباحة

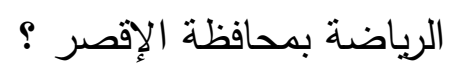

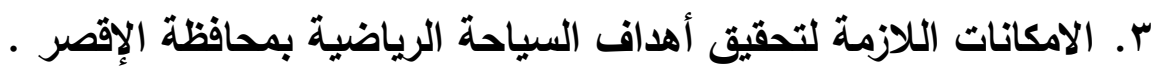

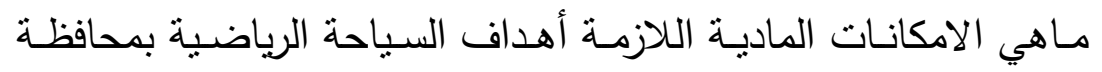

$$
\text { الإقصر }
$$

مـاهي الامكانـات البشـربة اللازمـة أهـداف السـياحة الرباضـية بمحافظــة

$$
\text { الإقصر }
$$




\section{مصطاحاث البحث:

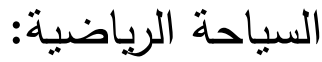

هي ذلك النوع من السياحة الذي ينتقل فيه الفرد بصفة مؤقتة من البلد الذي يعيش فيه على سبيل الاعتياد إلي بلد أخر بغرض المشاركة في المناسبات الرياضية وما يصاحبها من نشاطات مختلفة.

$(7: 0)$

ويقصد بها الانتقال من مكان الإقامة إلى مكان أخر لفترة مؤقتة بهدف ممارسة

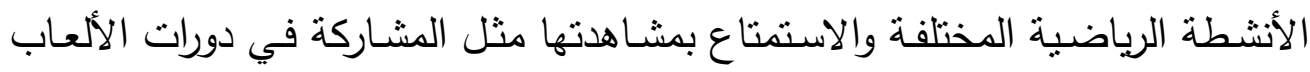
الأوليمبية وبطولات العالم وبطولات القارات، وتحقق السياحة الرياضية أهداف إنسانية

$$
\begin{aligned}
& \text { هامة . ( } \\
& \text { الجذب السياحي الرياضي : }
\end{aligned}
$$

هو استقطاب اكبر عدد ممكن من السياح نتيجة الأنشطة والبرامج الترويحية ،التي تقدمها الهيئات المعنية بالسياحة الرياضية، بما يلبى احتياجات ورغبات السائحين للترويح والاستمتاع بوقتهم. $(V: T)$

$$
\text { منهج البحاءات البحث: }
$$

استخدمت الباحثة المنهج الوصفي بالإستعانة بإحدي أساليب المسح الميداني

وذلك لمناسبته لطبيعة البحث وتحقيق أهدافه .

$$
\text { مجتمع البحث: }
$$

يتحدد مجتمع البحث الحالي من المسؤولين الفعليين عن الفنادق والاماكن

السياحيه بمحافظة الاقصر • 
ثالثاً : عينة البحث:

تم أختيار عينة البحث بالطريقة العشوائية وبلغ عددهم (0؛ ) مسؤول من اجمالي (7ه) مسئول من جميع العناصر المتمنلة في ادارة الفنادق السياحية والجدول التالي

\section{جدول (1)}

توزيع عينة البحث الاساسية.

\begin{tabular}{|c|c|c|c|}
\hline النسبة المئوية \% & العدد & العينـة & 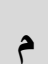 \\
\hline$\varepsilon Y . \wedge \Delta$ & $r \varepsilon$ & مديرو الفنادق & 1 \\
\hline r..ro & IV & مديرو الاقسام & r \\
\hline V. I $\varepsilon$ & $\varepsilon$ & مديرو الاستقبال & $r$ \\
\hline$\% \wedge . . r \Delta$ & $\leq 0$ & المجموع & $\varepsilon$ \\
\hline
\end{tabular}

يتضح من نتائج جدول( (1) أن توزيع عينة البحث نراوح بين (ع : ؟ب) بنسب

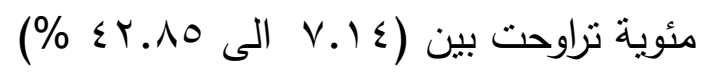

\section{جدول (r) \\ توصيف عينة البحث}

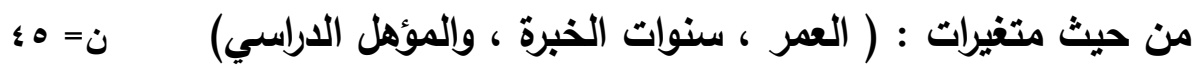

\begin{tabular}{|c|c|c|c|c|c|c|c|c|c|c|c|c|}
\hline \multicolumn{2}{|c|}{$7 .-00$} & \multicolumn{2}{|c|}{$0 \leq-0}$. & \multicolumn{2}{|c|}{$\leqslant q-\leqslant 0$} & \multicolumn{2}{|c|}{$\varepsilon \varepsilon-\varepsilon}$. & \multicolumn{2}{|c|}{$r q-r_{0}$} & \multicolumn{2}{|c|}{$r \leqslant-r}$. & \multirow{3}{*}{ (سنة) } \\
\hline$\%$ & ك & $\%$ & ك & $\%$ & & $\%$ & كs & $\%$ & ك & $\%$ & ك & \\
\hline 10.00 & v & Y & 11 & שT.rT & 10 & IV.VV & $\wedge$ & $\Lambda . \wedge \Lambda$ & $\varepsilon$ & $\%$. & - & \\
\hline
\end{tabular}




\section{تابع : جدول (r)}

\section{توصيف عينة البحث}

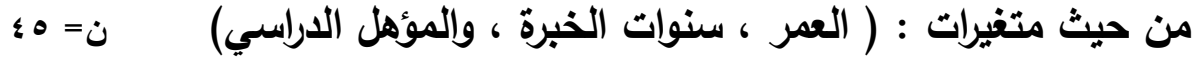

\begin{tabular}{|c|c|c|c|c|c|c|c|c|c|c|c|c|}
\hline \multicolumn{2}{|c|}{ أكثر من · r سنة } & \multicolumn{2}{|c|}{ من IV - IV منة } & \multicolumn{2}{|c|}{ من بنة - 17} & \multicolumn{2}{|c|}{ من 9 - } & \multicolumn{2}{|c|}{ من هنوات } & \multicolumn{2}{|c|}{ من 1- ؛ سنوات } & \multirow{3}{*}{ سنوات } \\
\hline$\%$ & ك & $\%$ & ك & $\%$ & ك & $\%$ & ك & $\%$ & ك5 & $\%$ & ك5 & \\
\hline r.1. & $1 \varepsilon$ & צ. & ir & IV.VV & $\wedge$ & IV.VV & $\Lambda$ & 7.74 & $r$ & $\%$. & - & \\
\hline \multicolumn{2}{|c|}{ أخرى } & \multicolumn{2}{|c|}{ دكتوراه } & \multicolumn{2}{|c|}{ ماجستير } & \multicolumn{2}{|c|}{ دبلوم عالي } & \multicolumn{2}{|c|}{ بكالوريوس } & \multicolumn{2}{|c|}{ دبلوم متوسط } & \\
\hline$\%$ & ك & $\%$ & ك5 & $\%$ & ك & $\%$ & ك5 & $\%$ & كs & $\%$ & ك & \\
\hline 7.79 & $r$ & $\%$. & - & $\%$. & - & $\%$. & - & Tr.r & $\leqslant \varphi$ & $\%$. & - & \\
\hline
\end{tabular}

يتضح من نتائج الجدول (Y) أنه بالنسبة لأعمار عينة البحث فقد تراوحت بين

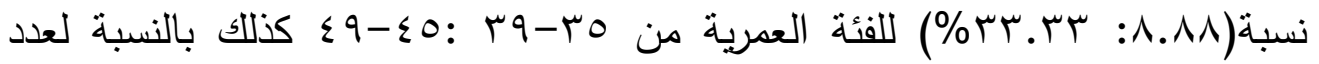

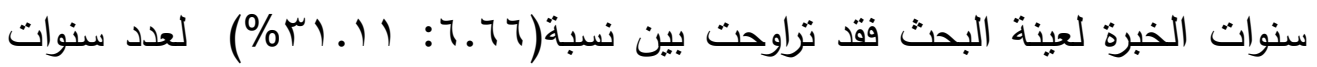
الخبرة من0-1 : V P. V سنة و وكذللك بالنسبة للمؤهل الدراسي لعينة البحث فقد

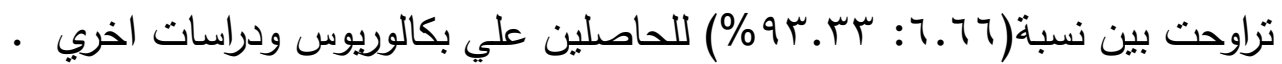

ثالثاً : الأدوات والوسائل المستخدمة في جمع البيانات :

استخدمت الباحثة الأدوات والوسائل التالية :

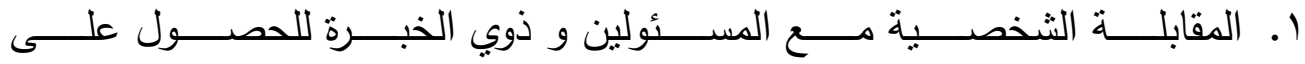

البيانات والمعلومات التي تفيد الدراسة .

r. الاستبيان : وهو من تصميم الباحثة .

r. فحص وثائق وسجلات (تحليل الدراسات - المراجع -مصادر الانترنيت ). 


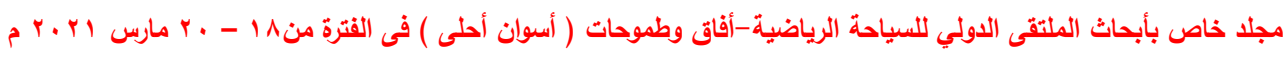

(العدد الثانى)

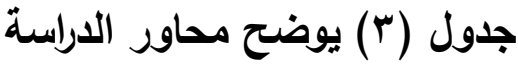

\begin{tabular}{|c|c|}
\hline الأهداف الخاصة بالسياحة الرياضية بمحافظةالاقصر & المحور الأول : \\
\hline 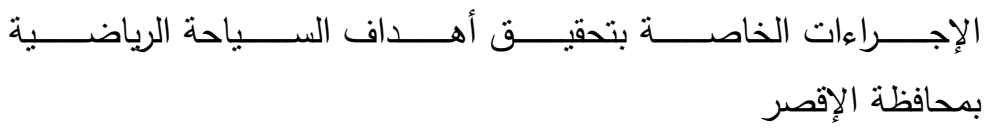 & المحور الثاني : \\
\hline 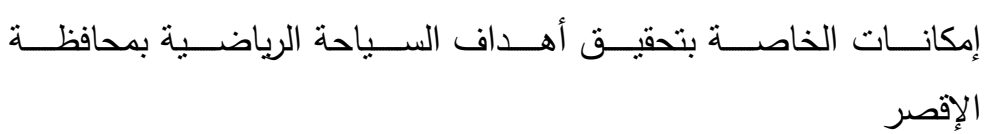 & المحور الثالث : \\
\hline
\end{tabular}

بعد أن حددت الباحثة محساور الدراسـة في ثـلاث محساور قامـت الباحثة بوضـع عدة عبـارات تتناسـب مـع كـل محسور مـن المحـاور ، وقد كـان مبـزان التقدير ثــائي في الإجابات على أسئلة الاستبيان وفقاً لجدول ( ) جدول (ع) يوضح محاور الدراسة

وعدد العبارات التي وضعتها الباحثة قبل عرضها على الخبراء

\begin{tabular}{|c|c|c|}
\hline عدد العبارات & اسم المحور & المحور \\
\hline rq & الأهداف الخاصة بالسياحة الرياضية بمحافظة الاقصر & الأول \\
\hline 10 & بمحافظة الاقصر & 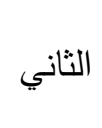 \\
\hline ro & 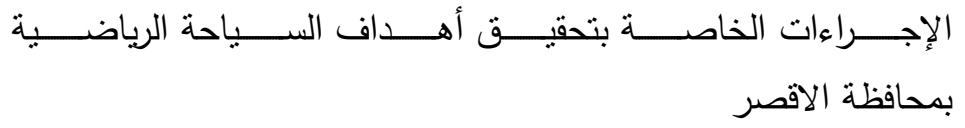 & الثالث \\
\hline 79 & الإجمالي & \\
\hline
\end{tabular}
رابعاً : المعاملات العلمية لاستمارة الاستبيان

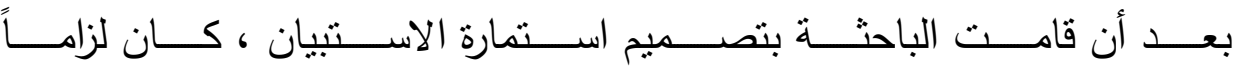

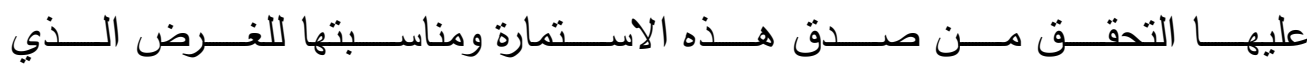
وضعت من أجله وقد استخدم فى ذلك صدق استمارة الاستبيان . 


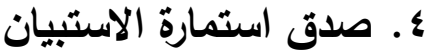

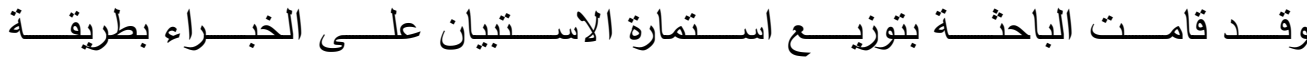

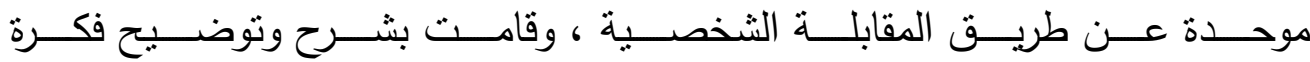

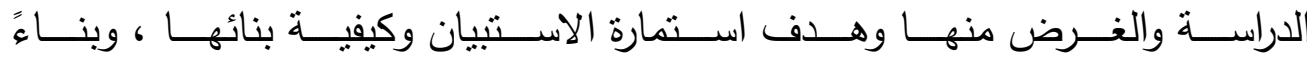

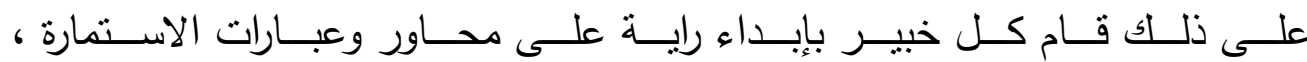

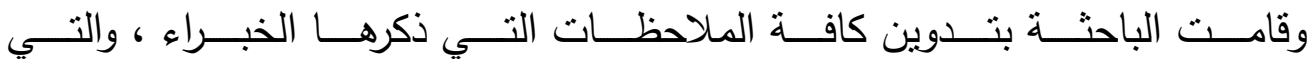

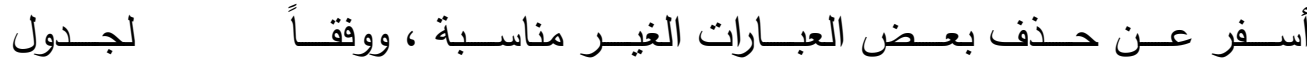

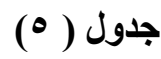

يوضح محاور الدراسة وعدد العبارات بعد حذف العبارات الغير مناسبة

\begin{tabular}{|c|c|c|c|}
\hline العبارات & نسبة موافقة الخبراء & اسم المحــور & 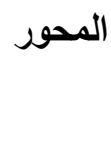 \\
\hline r & $\% 1 \ldots$ & الأهداف الخاصة بالسياحة الرياضية بمحافظة الإقصر & الأول \\
\hline r & $\% 1 \ldots$ & 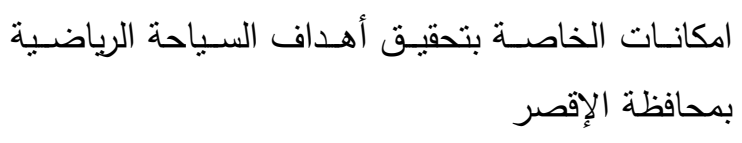 & الثانى \\
\hline 19 & $\% 1 \ldots$ & بمحافظة الإقصراءات الخاصـة بتحقيـق أهداف السياحة الرياضـية & 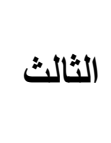 \\
\hline (1) & & الإجمـالي & \\
\hline
\end{tabular}

استخدمت الباحثة طريقة تطبيق استمارة الاستبيان وإعادة التطبيق على عينة استطلاعية من المسئولين عن السياحة بوزارة السياحة والهيئة الإقليمية لنتشيط السياحة بلاقصر وبلغ عددهم • ا مسئولين وذلك لاختبار ثبات استمارة الاستبيان ، ونم ذلك 


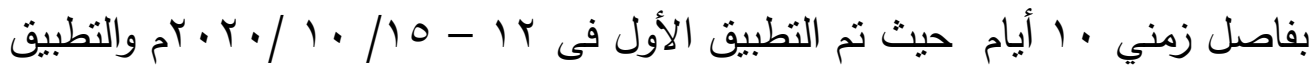

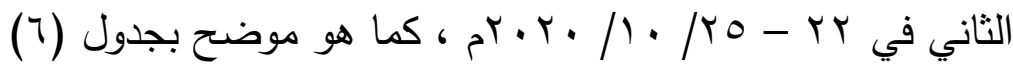

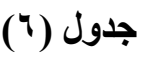

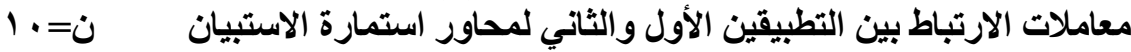

\begin{tabular}{|c|c|c|c|c|c|}
\hline معامـــــل & الثناني & الأول & عدد العبارات & المحـــاور & b \\
\hline & $\varepsilon \pm$ & $\varepsilon \pm$ & & & \\
\hline$* . . \wedge \wedge \mathrm{r}$ & r.roq & $r .7 \Lambda$ & Y & 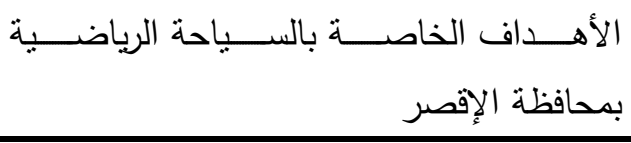 & 1 \\
\hline$* . . \wedge 9 \leqslant$ & $1.0 \varepsilon$ & $1 . r 0$ & 11 & 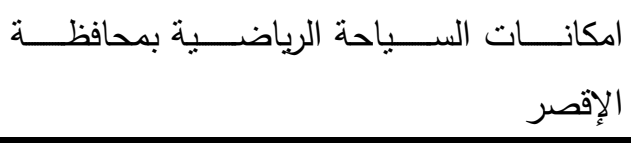 & r \\
\hline$* \cdot .9 \cdot r$ & $T . \Gamma \varepsilon$ & $r .1 T$ & 19 & 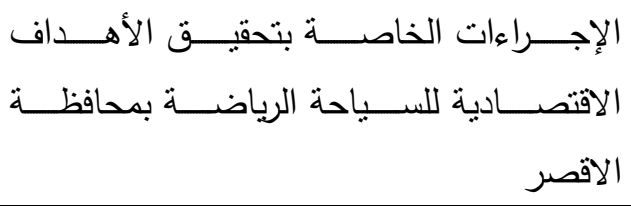 & $\varepsilon$ \\
\hline
\end{tabular}

ويتضـــح مــن الجـدول السـابق وجـود علاقــة ارتباطيـهـ دالــة إحصــائياً بــين

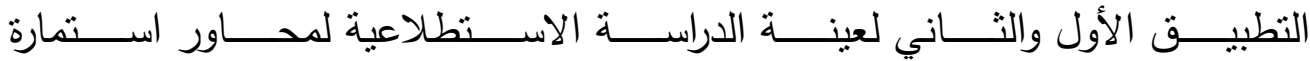
الاستبيان مما يدل على ثبات الاستمارة ومحاورها .

بعد التحقق من صدق وثبات استمارة الاستبيان تم الوصول إلى الصورة النهائية لكلإستمارة مرفق ( ) 


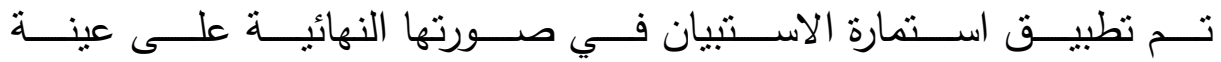

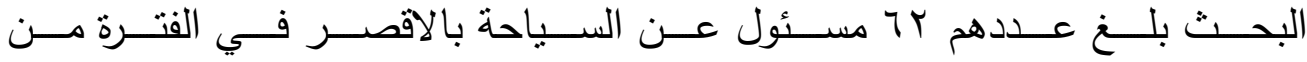
•

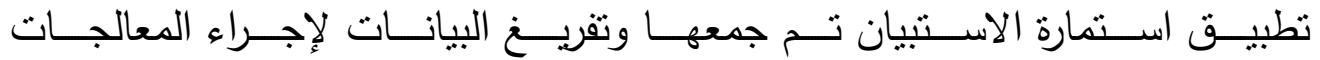

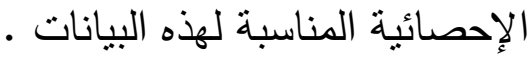

\section{المعالجات الإحصائية}

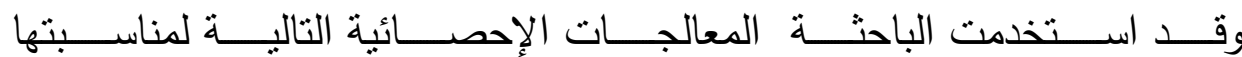
لطبيعة البحث : ل ل

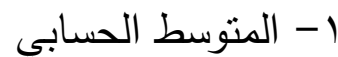
r- ب - ب الانحراف المعياري r- معامل الارنباط

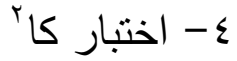

وتم استخدام ميزان تقدير ثنائي كما يلي :$1=8$ $r=$ نعم

$$
\text { المتوقع }
$$

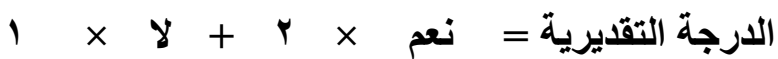

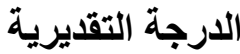

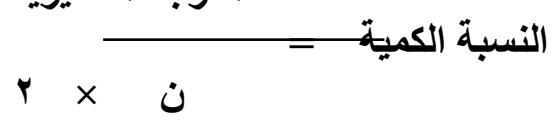

مج ( س - س )

$1-\dot{0}$ 


$$
\text { المتوسط ( سم) = مج س }
$$

\section{المعوقات التي تعرضت لها الباحثة}

ا ـ قلة المراجع العلمية المرتبطة بالبحث خاصة المراجع الخاصة بالسياحة

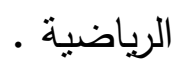

r. احجمام بعض المسئولين بوزارة الثباب ووزارة السياحة عن الإدلاء بأي معلومات تقبد البحث ، على الرغم من قيام الباحثة بطمئنتهم بان هذه المعلومات تستخدم من اجل خدمة البحث العلمي فقط . عرض التتائج ومناقشتها وتفسيرها ( ) جدول (v)

\begin{tabular}{|c|c|c|c|c|c|c|}
\hline \multirow[t]{2}{*}{ الارجة } & \multicolumn{2}{|c|}{$\gamma$} & \multicolumn{2}{|c|}{ نعم } & \multirow[t]{2}{*}{ 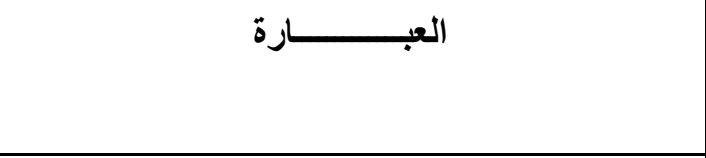 } & \multirow{2}{*}{ رق العبار } \\
\hline & 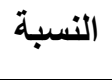 & عدد & 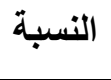 & عدد & & \\
\hline 1.0 & $\begin{array}{l}\mu_{1} \\
\%\end{array}$ & 19 & $\% 49$ & $\varepsilon r$ & التعرف على الأماكن السياحية بمحافظة الاقصر. & 1 \\
\hline 1.1 & $\begin{array}{l}\text { rq } \\
\%\end{array}$ & 17 & $\% \vee \leqslant$ & $\leq 7$ & السياحير. ـــــات الرياضية التـي تسـاهم في المجـال & $r$ \\
\hline 110 & $\begin{array}{l}10 \\
\%\end{array}$ & 9 & $\%$ ^० & r & 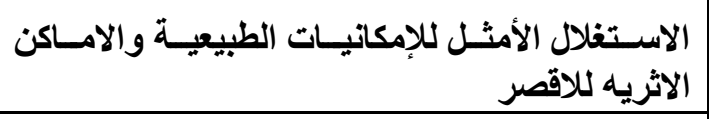 & $r$ \\
\hline 111 & i. & 7 & $\% 9$. & 07 & 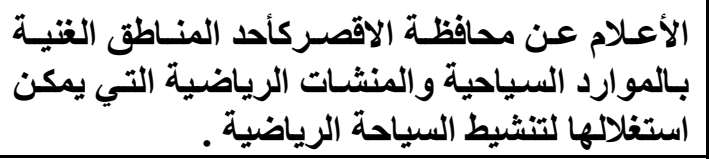 & $\varepsilon$ \\
\hline 117 & $\%$ & r & $\% 9 r$ & ov & مثأبدة ألوان جديدة من الرياضية التحين بغرض ممارسة أو & 0 \\
\hline
\end{tabular}
عرض ومناقشة نتائج المحور الأول : الأهداف

الأهداف العامة للسياحة الرياضية بمحافظة الاقصر 


\begin{tabular}{|c|c|c|c|c|c|c|}
\hline $11 \%$ & $\begin{array}{l}19 \\
\%\end{array}$ & Ir & $\% \wedge 1$ & 0 . & 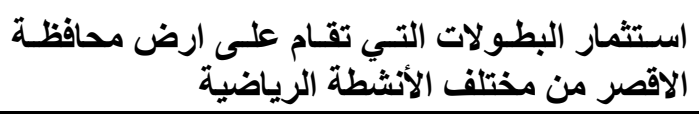 & 7 \\
\hline 117 & ir & $\Lambda$ & $\% \wedge \vee$ & 0 \& & 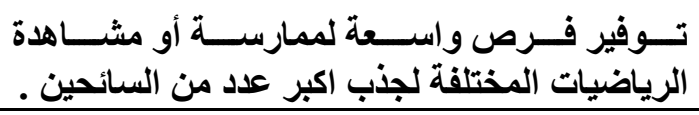 & $V$ \\
\hline 117 & $\begin{array}{ll}14 \\
\%\end{array}$ & $\Lambda$ & $\% \wedge \vee$ & $0 \leq$ & الاستثلثمار الأمثل لوقت الفراغ لممارسـة الرياضــات & $\Lambda$ \\
\hline $11 r$ & $\begin{array}{l}19 \\
\%\end{array}$ & Ir & $\% \wedge 1$ & 0 . & بمحافظة الاقصة من الامـاكن الاثريـة و السياحية المتوفرة & 9 \\
\hline
\end{tabular}

الأهداف الاقتصادية الخاصة بالسياحة الرياضية بمحافظة الاقصر

\begin{tabular}{|c|c|c|c|c|c|c|}
\hline 119 & $\% \wedge$ & 0 & $\% 9 r$ & OV & 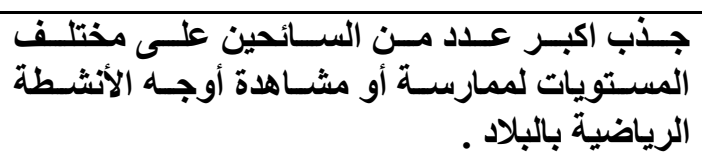 & 11 \\
\hline $11 \mathrm{~V}$ & $\begin{array}{l}11 \\
\%\end{array}$ & V & $\%^{\wedge \wedge}$ & 00 & 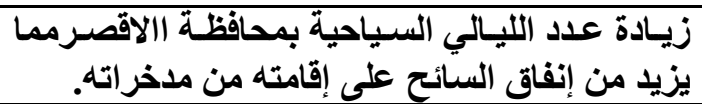 & Ir \\
\hline$T r$. & $\%$ & $\varepsilon$ & $\% 9 \varepsilon$ & 01 & إنعاثش المنشات الفندقية في غير مواسم الذروة . & ir \\
\hline $11 \%$ & $\begin{array}{l}11 \\
\%\end{array}$ & 11 & $\% \wedge r$ & 01 & 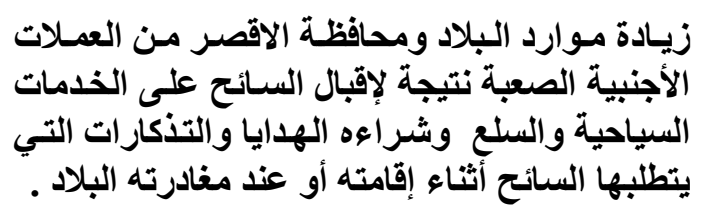 & $1 \varepsilon$ \\
\hline Ir. & $\%$ & $\varepsilon$ & $\% 9 \varepsilon$ & $0 \wedge$ & زيادة فرص العمل وتثغيل العمالة . & 10 \\
\hline $11 \pi$ & $\begin{array}{l}11 \\
\%\end{array}$ & 11 & $\% \wedge r$ & 01 & 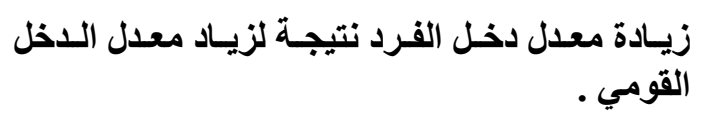 & 17 \\
\hline 111 & $\begin{array}{l}r 1 \\
\%\end{array}$ & ir & $\% \vee q$ & $\leqslant 9$ & زيادة المنشات الرياضية بمحافظة الاقصر. & IV \\
\hline 1.9 & $\begin{array}{l}r \leqslant \\
\%\end{array}$ & 10 & $\% \vee 7$ & $\leqslant V$ & جولف - جنكال المنشات الرياضية ذات السمة السياحية ( & 11 \\
\hline 10 & $\begin{array}{l}74 \\
\%\end{array}$ & $r q$ & $\% r v$ & rr & الرياضية مجموعـة مــن الفتـانين فــي المناســـات & 19 \\
\hline
\end{tabular}




\begin{tabular}{|c|c|c|c|c|c|}
\hline$\wedge 1$ & $\begin{array}{l}79 \\
\%\end{array}$ & $\leqslant r$ & $\%{ }^{m}$ & 19 & 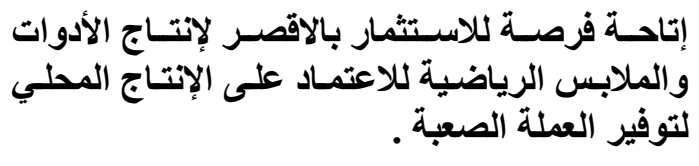 \\
\hline
\end{tabular}

rus

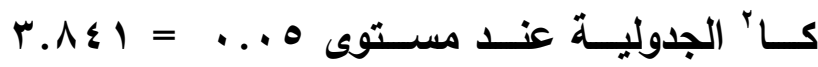

$$
\begin{aligned}
& \text { الجدولية عند مستوى = هر } 7.7
\end{aligned}
$$

اتقفت آراء العينة على أن أهم الأهداف العامـة للسياحة الرياضية بمحافظة الاقصر

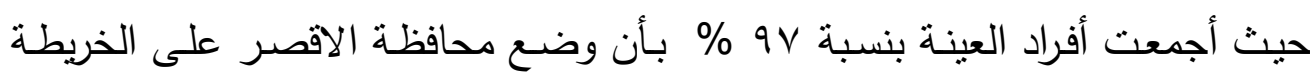

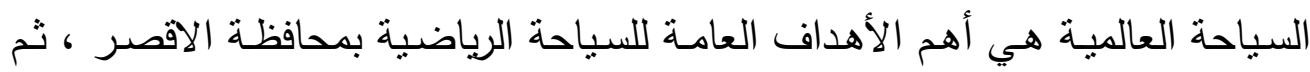

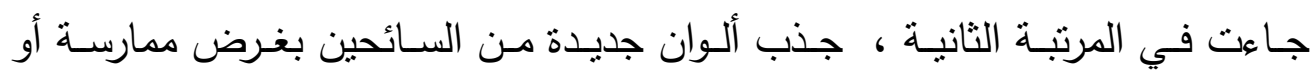

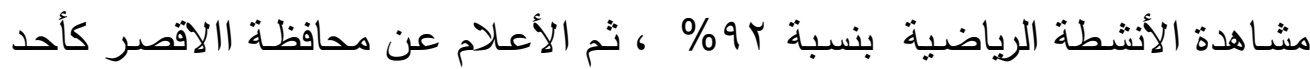

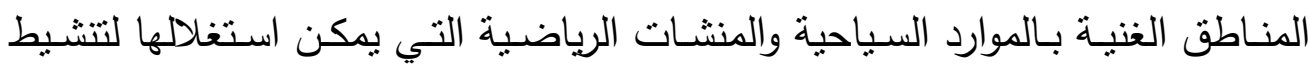
السياحة الرياضية ، في المرتبـة الثالثة بنسبة ، 9\% ، ثم جاءت في المرتبـة الرابعـة

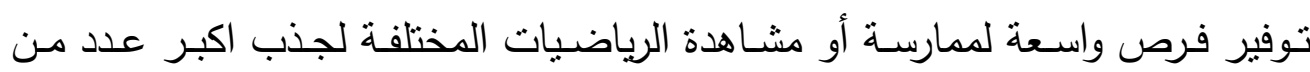
السائحين والاستثمار الأمثل لوقت الفراغ لممارسة الرياضات المختلفة. بنسبة NV

ويالنسـبة للأهـاف الاقتصـادية الخاصـة بالسـياحة الرياضـية بمحافظـة الاقصـرفقد

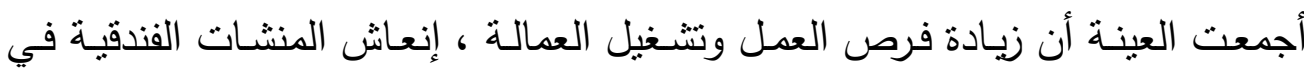
غير مواسم الذروة هي أهم الأهداف الاقتصادية للسياحة الرياضية بمحافظة الاقصر وجاءت بنسبة §9\% ، ثم جاءت في المرنبة الثانية ، جذب اكبر عدد من السائحين

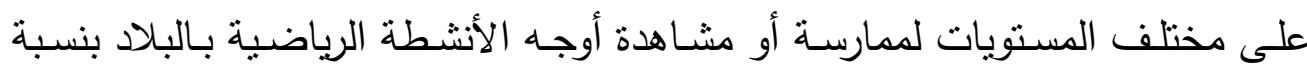
r\% ، ، ثم جاءت فى المرتبة الثالثة زيادة عدد الليالي السياحية بمحافظة الاقصر مما

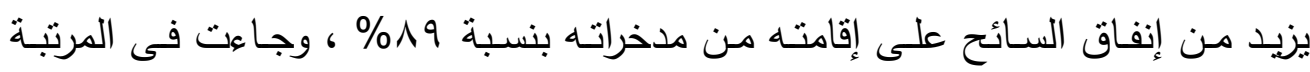

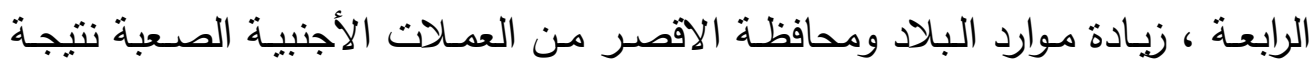


لإقبال السائح على الخدمات السياحية والسلع ع وشراءه الهدايا والتذكارات التي يتطلبها

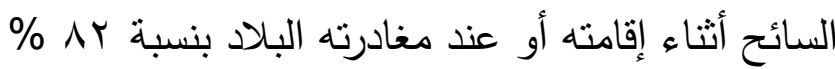

$$
\text { جدول ( ) (1) (1) }
$$

عرض ومناقشة نتائج المحور الثانى : الإمكانات

\section{عرض ومناقشة النتائج الخاصة الإمكانات الطبيعية السياحة الرياضية بمحافظة الاقصر}

\begin{tabular}{|c|c|c|c|c|c|}
\hline \multicolumn{2}{|c|}{$y$} & \multicolumn{2}{|c|}{ نعم } & \multirow{2}{*}{ 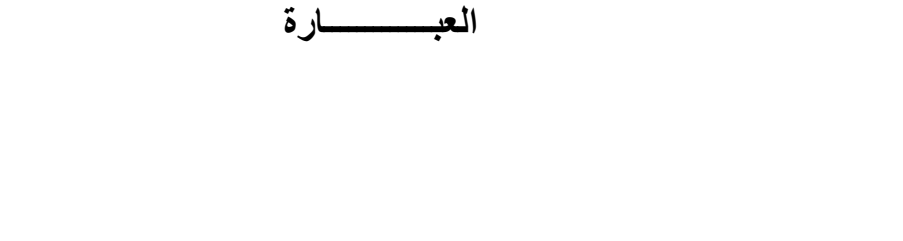 } & \multirow{2}{*}{ العبارة } \\
\hline النسب & عدد & أ & عدد & & \\
\hline$\%$ & r & $\begin{array}{l}9 \\
q\end{array}$ & 7. & اعتدال الطقس اغلب فترات العام . & $r v$ \\
\hline$\%$ & r & $\begin{array}{l}q \\
v\end{array}$ & 7. & نهر النيل الممتد على طول المدينة الصالحة لممارسة رياضه الكياك & $r \Lambda$ \\
\hline$\%{ }^{\circ}$ & $r$ & $\begin{array}{l}q \\
0 \\
\%\end{array}$ & $0 \wedge$ & الاماكن الاثاريه & $r q$ \\
\hline$\%$ & $r$ & $\begin{array}{l}9 \\
0 \\
\%\end{array}$ & $0 \wedge$ & المزارات السياحية & $\varepsilon$ \\
\hline
\end{tabular}

الإمكانات المادية اللازمة لتحقيق أهداف السياحة الرياضية بمحافظة الاقصر

\begin{tabular}{|c|c|c|c|c|c|}
\hline$\% \wedge$ & 0 & $\begin{array}{ll}94 \\
\%\end{array}$ & OV & توفير الاعتمادات المالية إقامة منثات السياحة الرياضية وصياتتها . & $\leqslant r$ \\
\hline$\% 10$ & 9 & $\begin{array}{ll}10 \\
\%\end{array}$ & or & توفير الاعتمادات المالية لإقامة المناسبات الرياضية . & \& \\
\hline$\% r V$ & IV & $\begin{array}{l}V \Psi \\
\%\end{array}$ & $\leqslant 0$ & تلمشيّركين الاعتمادات المالية لتقليم الجوائز والميداليات والهدايا والتذكارات & $\leqslant 0$ \\
\hline$\%$ & $r$ & $\begin{array}{l}9 V \\
\%\end{array}$ & 7. & توفير الاعتمادات المالية للإعلان عن المناسبات الرياضية والتسويق الجيد لها & $\leqslant 7$ \\
\hline$\%$ & 19 & $\begin{array}{l}79 \\
\%\end{array}$ & $\varepsilon r$ & توفير الاعتمادات المالية توفير أجهزة التدريب وأماكن صياتتها . & $\varepsilon V$ \\
\hline$\%^{r}$ & r & $9 V$ & 7. & توفير أماكن خاصة بالإعاثة و الإقامة مثل الفنادق والقزى الأولمبية المجهزة & $\leqslant \Lambda$ \\
\hline
\end{tabular}




\begin{tabular}{|c|c|c|c|c|c|}
\hline & & $\%$ & & الامكانات الرياضية وأماكن الترفيه والترويح . & \\
\hline$\%$ rq & 11 & $\begin{array}{l}\text { VI } \\
\%\end{array}$ & $\varepsilon \varepsilon$ & الأسعار المناسبة للخدمات المقدمة للسائحين . & $\varepsilon 9$ \\
\hline$\% 17$ & $1 \cdot$ & $\begin{array}{l}\Lambda \varepsilon \\
\%\end{array}$ & or & النقل السياحي البري - الجوي - البحري للسائحين . & ๑. \\
\hline$\% 11$ & $\mathrm{~V}$ & $\begin{array}{l}19 \\
\%\end{array}$ & 00 & تو افر أماكن ممارسة الألعاب مثل الملاعب والصالات المغطاة . & 01 \\
\hline$\%$ & 19 & $\begin{array}{l}79 \\
\%\end{array}$ & $\varepsilon$ & الاخل المادي للسيائحين للقيام برحلات سياحية داخلية وخارجية . & or \\
\hline$\%{ }^{0}$ & $r$ & $\begin{array}{l}90 \\
\%\end{array}$ & $\bullet 9$ & توفير المطارات ووسائل النقل المختلفة والسكك الحديدية . . & or \\
\hline$\%$ Y & 17 & $\begin{array}{l}V \varepsilon \\
\%\end{array}$ & $\varepsilon 7$ & شركات ومكاتب السياحة . & ๑ \\
\hline$\%{ }^{0}$ & $r$ & $\begin{array}{l}90 \\
\%\end{array}$ & 09 & توافر وسائل الإعلام و الاتصالات المختلفة مثل الأقمار الصناعية ـ. & 00 \\
\hline$\%$ & $\varepsilon$ & $\begin{array}{l}9 \leq \\
\%\end{array}$ & $\Delta \wedge$ & وجود المستشفيات القريبة من منشات السياحة الرياضية . & 07 \\
\hline$\%$ & $\varepsilon$ & $\begin{array}{l}9 \varepsilon \\
\%\end{array}$ & $\bullet \wedge$ & وجود عربات الإسعاف المجهزة لنقل اللاعبين والسائحين المصابين . & ov \\
\hline
\end{tabular}

عرض ومناقشة النتائج الخاصة الإمكانات البشرية اللازمة لتحقيق أهداف السياحه الرياضيه

\begin{tabular}{|c|c|c|c|c|c|}
\hline $\mathbf{0}^{4}$ & $r$ & $\begin{array}{l}q \\
v \\
\%\end{array}$ & 7. & تو افر كوادر مؤهلة للعمل في مجال السياحة الرياضية & $0 \wedge$ \\
\hline$\sigma^{\top}$ & $r$ & $\begin{array}{l}q \\
v \\
\%\end{array}$ & 7. & التنسيق بين كليات التربية الرياضية وكلية التيات السياحة و الفنادق لتخريج كوادر & 09 \\
\hline$\% 1$. & 7 & $\begin{array}{c}9 \\
\text { q } \\
\%\end{array}$ & 07 & إجادة الخريجين إحدى اللغات الأجنبيةة . & 7. \\
\hline$\%$ \%r & r. & $\begin{array}{l}\overline{1} \\
\hat{1} \\
\%\end{array}$ & $\varepsilon r$ & توافر الخبرة في مجال العلاقات العامة . & 71 \\
\hline$\%{ }^{\circ}$ & $r$ & $\begin{array}{l}q \\
0 \\
\%\end{array}$ & 09 & إلمام القادة في مجال السياحة بالأنشطة الرياضية وطرق تنظيم المناسبات & $7 r$ \\
\hline$\%{ }^{0}$ & $r$ & $\begin{array}{l}9 \\
0 \\
\%\end{array}$ & 89 & السيامة القادة في مجال التربية الرياضية بالأنشطة السياحية وطرق جذب وتنثيط & 74 \\
\hline
\end{tabular}




\begin{tabular}{|c|c|c|c|c|c|}
\hline$\%$ & Or & $\begin{array}{l}1 \\
1 \\
\%\end{array}$ & 1. & تشجيع الكوادر القيادية على إجراء البحوث في مجال السياحة الرياضية . & $7 \varepsilon$ \\
\hline$\%$ & r & $\begin{array}{l}q \\
v \\
\%\end{array}$ & 7. & توافر الكوادر المؤهلة لتنظيم المسابقات الرياضية للسائحين . & 70 \\
\hline$\%$ & 19 & $\begin{array}{l}9 \\
9 \\
9\end{array}$ & $\varepsilon r$ & توافر أخصائيون العلاج الطبيعي . & 79 \\
\hline$\%$ & $\varepsilon$ & $\begin{array}{l}9 \\
9 \\
\%\end{array}$ & $0 \wedge$ & إبرامجاد الكوادرة الرياضية المتخصصية في برامج التشثيط والتسويق والتخطيط & $7 V$ \\
\hline$\%$ & $\varepsilon$ & $\begin{array}{l}9 \\
\varepsilon \\
\%\end{array}$ & $0 \wedge$ & توافر الإداريون . & 71 \\
\hline$\%{ }^{14}$ & $\Lambda$ & $\begin{array}{l}\Lambda \\
V \\
\% \\
\end{array}$ & $0 \leqslant$ & توافر المرشدون السياحيون . & 79 \\
\hline$\%{ }^{0}$ & $r$ & $\begin{array}{l}9 \\
0 \\
\%\end{array}$ & 09 & توافر المترجمون للغات المختلفة . & $\mathrm{V} \cdot$ \\
\hline$\% \varepsilon$. & Yo & $\begin{array}{c}4 \\
\% \\
\%\end{array}$ & $r v$ & توافر مشرفين التغذية & VI \\
\hline$\% \%^{0}$ & $r$ & $\begin{array}{l}9 \\
0 \\
\%\end{array}$ & 09 & المصابين الأطبـاء الأخصــائيون لإجـراء الإســافات الأوليـة للاعبـين والســائحين & VY \\
\hline$\%$ & Or & $\begin{array}{l}1 \\
\% \\
\%\end{array}$ & 9 & تنظيم دورات صقل للمشتظلين بهذا القطاع للإطلاع على الجايد فى هذا المجال . & $V r$ \\
\hline$\%^{0}$ & $r$ & $\begin{array}{c}9 \\
0 \\
\%\end{array}$ & 09 & توافر عمال النظافة. & $V \varepsilon$ \\
\hline$\% r^{q}$ & 11 & $\begin{array}{c} \\
1 \\
\%\end{array}$ & $\varepsilon \varepsilon$ & توافر فنيون الصيانة للأدوات والأجهزة & Vo \\
\hline$\%$ & 11 & $\begin{array}{l}\hat{\Lambda} \\
\hat{r} \\
\%\end{array}$ & 01 & توافر فنيون الإضاءة والكهرباء . & $\sqrt{74}$ \\
\hline
\end{tabular}


يتضـح من جدول ( ^ ) والخـاص بالامكانـات الطبيعيـة بمحافظة الاقصر أن أهم الامكانات الطبيعة بمحافظة الاقصر هي اعتدال الطقس اغلب فترات العام ، و نهر النيل الممتد على طول المدينة الصالحة لممارسة رياضـة الكياك ، الامـاكن الاثريـة ، وجاءت بنسبة \9\% ، ثم يليها فى المرتبـة الثانيـة المزارات السياحية ، وجـاءت

$$
\text { بنسبة 90\% }
$$

وأمـا الإمكانـات المادية الخاصـة بالسياحة الرياضية بمحافظة الاقصر، فنجد أن أهم الإمكانـات الماديـة الخاصـة بالسياحة الرياضـية بمحافظـة الاقصـر هـي توفير أمـاكن خاصـة بالإعاشــة والإقامـة مثثل الفنادق والقرى الأولمبيـة المجهزة الامكانـات الرياضية وأماكن الترفيه والترويح ، و توفير الاعتمادات المالية للإعلان عن المناسبات الرياضية والتسويق الجيد لها بنسبة V9\% ، وجاءت فى المرتبة الثانية توافر وسائل الإعلام و الاتصالات المختلفة مثل الأقمار الصناعية ، و توفير المطارات ووسائل النقل المختلفة والسكك الحديديـة بنسبة 90\% ، ثم جـاءت فى المرتبـة الثالثة ، وجـود المستشـفيات القريبـة مـن منشــات السـياحة الرياضـية ، و وجـود عربـات الإسـعاف المجهزة لنقـل اللاعبين والسائحين المصابين بنسبة ؟9\% ، ثم جاءت فى الرابعة توفير الاعتمادات المالية إقامة منشات السياحة الرياضية وصيانتها ب9 9 9

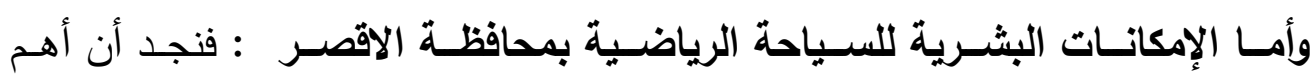
الإمكانات البشرية الخاصـة بالسياحة الرياضية بمحافظة الاقصر هي ، توافر كوادر مؤهلـة للعمـل في مجـال السياحة الرياضية ، التنسـيق بـين كليـات التربيـة الرياضية وكليات السياحة والفنادق لتخريج كوادر مؤهلة للعمل في مجال السياحة الرياضية ، توافر الكوادر المؤهلة لتنظيم المسابقات الرياضية للسائحين وجاءت بنسبة V9\% ، ثم جاءت فـى المرتبـة الثانيـة إلمـام القادة في مجال السياحة بالأنشطة الرياضية وطرق تتظيم المناسبات ، إلمام القادة في مجال التربية الرياضية بالأنشطة السياحية وطرق جذب وتتشيط السياحة ، توافر عمـال النظافـة ، توافر المترجمون للغـات المختلفة ، توافر الأطباء الأخصـائيون لإجراء الإسـعافات الأولية للاعبين والسـائحين المصـابين 
وجـاءت بنسـبة 90\% ، ويسأتي بعـدها فـى المرتبـة الثالثـة إعـداد الكـوادر الرياضـية المتخصصة في برامج النتشيط والتسويق والتخطيط لبرامج السياحة الرياضية ، و توافر الإداريون بنسبة ؟9\% ، ثم جاءت فى المرتبة الرابعة إجادة الخريجين إحدى اللغات الأجنبية بنسبة . 9 \% 9

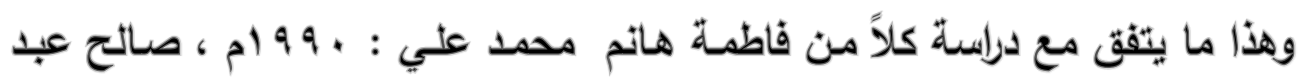

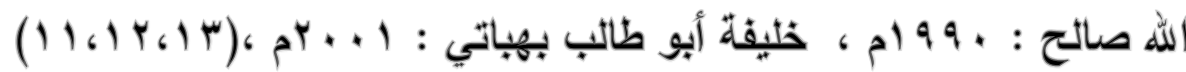

\section{جدول ( )}

\section{عرض ومناقشة نتائج المحور الرابع : الإجراءات الخاصة}

الإجراءات الخاصة بتحقيق الأهداف الاقتصادية للسياحة الرياضية بمحا

\begin{tabular}{|c|c|c|c|c|c|}
\hline \multicolumn{2}{|l|}{ ע } & \multicolumn{2}{|c|}{ ن انمم } & \multirow[t]{2}{*}{ 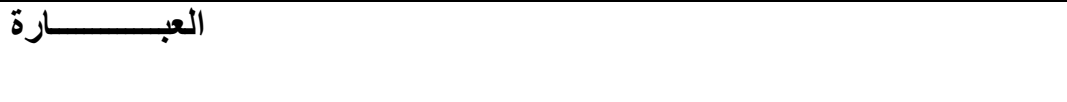 } & \multirow{2}{*}{ 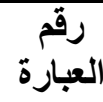 } \\
\hline النس & عدد & النسبة & عدد & & \\
\hline 11 & $\mathrm{~V}$ & $\% \wedge 9$ & 00 & 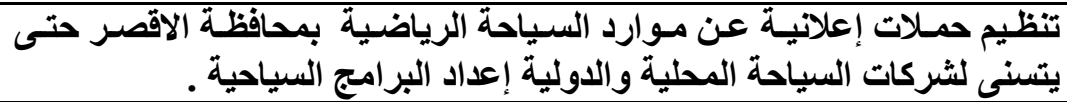 & VV \\
\hline $1 \cdot$ & 9 & $\%$ & 07 & العمل على جذب الاستثمـارات فـى مجـال السياحة الرياضـية وإعداد الإمكانـات & $\vee \wedge$ \\
\hline r & Y & $\%$ & \& & جذب الاستثمارات العالمية للاستثمار في السياحة الرياضية . & Vq \\
\hline 70 & $\varepsilon$. & $\%$ & rr & تنظيم حملات إعلانية خاصة بمختلف الإقامة الحالية منها و الجديدة . & $\Lambda$. \\
\hline$Y \varepsilon$ & 1. & $\% \vee 7$ & $\varepsilon V$ & الاتصال بالرعاة الرسميين لرعاية الإحداث الرياضية عند إقامتها . & $\Lambda 1$ \\
\hline Y乏 & 1. & $\% \vee 7$ & $\varepsilon V$ & الاتصال بالمساهمين والمستثمرين لتمويل مشرو عات السياحة الرياضية & $\Lambda Y$ \\
\hline YV & IV & $\% \vee r$ & $\varepsilon 0$ & الاهتمام بالتسويق الجيد للمنتج المصري من السياحة الرياضية . & $\Lambda \mu$ \\
\hline 17 & $1 \cdot$ & $\% \wedge \varepsilon$ & or & توافز الخدمات المقدمة للسائحين والعمل على تتوعها واختلافها . & $\Lambda \varepsilon$ \\
\hline o & $\varepsilon$ & $\% 9 \leq$ & $0 \wedge$ & 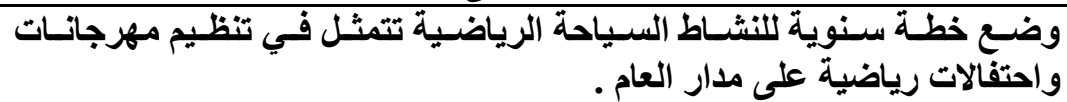 & 10 \\
\hline $\mathbf{o}^{\mathbf{r}}$ & r & $\% 9 \mathrm{~V}$ & 7. & الإعـاحلانة عـن مـوارد السـياحة الرياضـية بالاقصـر وإعـداد الكتيبـات والخـرائط & $\Lambda \neg$ \\
\hline${ }^{4}$ & r & $\% 9 \mathrm{~V}$ & 7. & العمل على تنوع المناسبات والمهرجانات واختلافها وإقامتها على مدار العام. & $\Lambda V$ \\
\hline
\end{tabular}


الإجراءات الخاصة بتحقيق الأهداف الاجتماعية للسياحة الرياضية بمحافظة الاقصر

\begin{tabular}{|c|c|c|c|c|}
\hline rq & $\% \mathrm{mV}$ & $r r$ & إلقامة فرعة الرياضية بمحافظة للسياحة الرياضية في وزارة السياحة يعمل على وضع برامج & $\wedge \wedge$ \\
\hline Y & $\%$ & «1 & الإعفاعات الجمركية على الأجهزة والأدوات الرياضية لتدعيم السياحة الرياضية & $\wedge 9$ \\
\hline 11 & $\% \vee 1$ & $\varepsilon \varepsilon$ & الاستعانة بالخبراء العالميين في مجال السياحة الرياضية . & 9. \\
\hline & & & تسهيل إجراعات استيراد الأدوات والأجهزة الرياضية . & 91 \\
\hline $1 \mathrm{~V}$ & $\% \vee V$ & $\leqslant 0$ & إعداد الاورات التدريبية السياحية للعاملين في المجال الرياضي . & 94 \\
\hline 11 & $\% \wedge r$ & 01 & إعداد الدورات التدريبية الرياضية للعاملين في المجال السياحي . & $9 \leq$ \\
\hline 7 & $\% 9$. & 07 & الاهتمام بالتدريب العملي والتعاون بين كليات التربية الرياضية وكليات السياحة & 90 \\
\hline
\end{tabular}

يتضح من جدول ( 9 ) والخاص بالإجراءات الخاصة بتحقيق الأهداف الاقتصادية للسياحة الرياضية بمحافظة الاقصر، أن أهم الإجراءات الخاصـة بتحقيق الأهداف

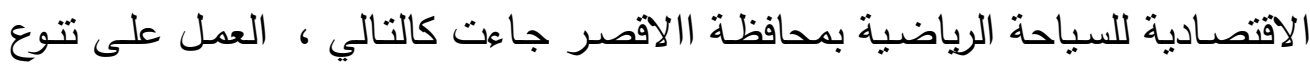
المناسبات والمهرجانات واختلافها وإقامتها على مدار العام ، و الإعـلان عن موارد

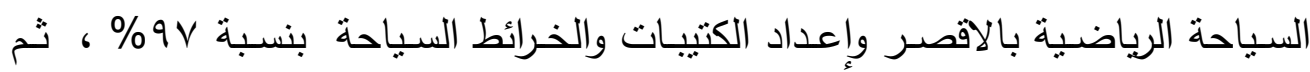
جاءت في المرتبة الثانية وضع خطة سنوية للنشاط السياحة الرياضية تتمثل في تتظيم

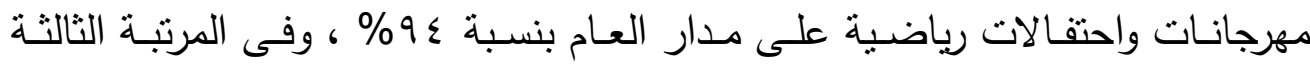
جاءت العمل على جذب الاستثمارات فى مجال السياحة الرياضية وإعداد الإكانات اللازمـة لها بنسبة ، 9\% ، ثم جاءت في المرتبـة الرابعة تتظيم حمـلات إعلانيـة عن مـوارد السياحة الرياضية بمحافظـة الاقصـر حتى يتسـى لثـركات السياحة المحليـة

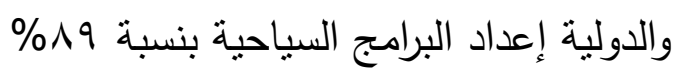

وأما الإجراءات الخاصة بتحقيق الأهداف الاجتماعية للسياحة الرياضية بمحافظة الاقصر ، فنجد أن أهم الإجراءات الخاصـة بتحقيق الأهداف الاجتماعيـة للسياحة

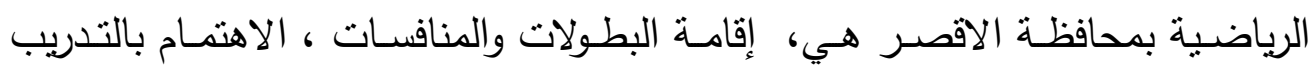
العملي والتعاون بين كليات التربية الرياضية وكليات السياحة والفنادق للعمل فى مجال السياحة الرياضية بنسبة ـ9\% ، ثم جاءت فى المرتبة الثانية إعداد الدورات التذريبية الرياضية للعاملين فى المجال السياحي بنسبة rیر\% ، وجاءت فى المرتبة الثالثة إعداد 
الدورات التدربيية السياحية للعـاملين فى المجال الرياضـي بنسبة بو\% ثم يليها فى المرتبة الرابعة الاستعانة بالخبراء العالميين فى مجال السياحة الرياضية

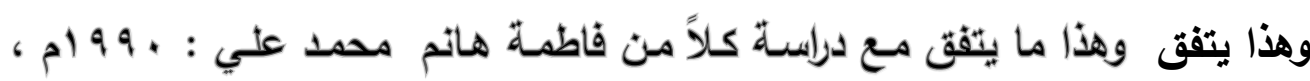

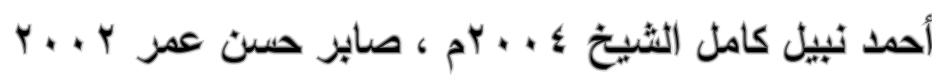
النتائج والتوصيات في ضوء مجال البحث والهدف منـه ، واستتاداً على مـا تم من إجراءات ومعالجات إحصائية ، وفى نطاق مجتمع البحث وفى حدود عينة الدراسة وبعد عرض ومناقتـة الدراسة توصلت الباحثة إلى النتائج التالية : المحور الأول

بالنسبة للأهداف السياحة الرياضية بمحافظة الاقصر؟ توصلت الدراسـة إلحى أن أهم أهداف للسباحة الرياضية بمحافظة الاقصر مايلي : - وضـع موارد محافظـة الاقصـر السياحية على الخريطـة السياحة العالميـة

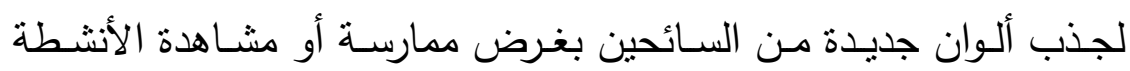
الرباضية - الأعـلام عـن محافظـة الاقصـر كأحـد المنـاطق الغنبـة بالامــاكن الاثريـه

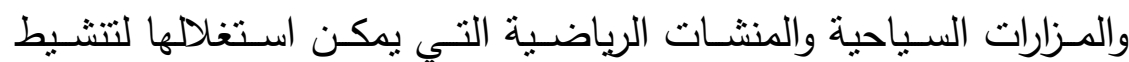

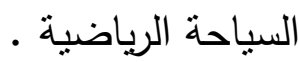
- توفير فرص واسعة لممارسة أو مشاهدة الرياضيات المختلفة لجذب اكبر عدد من السائحين 
- اسـتمار البطولات التي تقام على ارض محافظـة الاقصـر مـن مختلف الأنشطة الرياضية - الاستغلال الأمثل للإمكانيات الطبيعية والاثريه بمحافظة الاقصر - - الاستفادة من نهر النيل والفنادق السياحية المتوفرة بمحافظة الاقصر

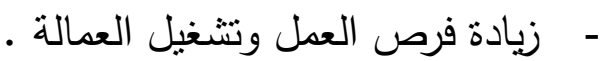
- - زيادة عدد الليالي السياحية بمحافظة الاقصر مما يزيد من إنفاق السائح على إقامته من مدخراته.

- زيادة موارد البلاد ومحافظة الاقصر من العملات الأجنبية الصعبة نتيجة لإقبال السـائح على الخدمات السياحية والسلع ع وشراءه الهدايا والتذكارات التي يتطلبها السائح أثناء إقامته أو عند مغادرته البلاد . - زيادة معدل دخل الفرد نتيجة لزباد معدل الدخل القومي المسـاهمة في بنـاء البنيـة التحيـة الرياضية مثنل الاستادات والملاعب والقرى الأولمبية. تتشيط حركة السياحة الداخلية والخارجية . 


\section{المحور الثانى}

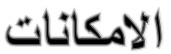

\section{أظظهرث الثتائج أن أهم الإمكاثات بمحاقظة الاقصر التي بمكن أن تشاهم} في تحقيق أهداف البياحة الثرباضبة بمحافظة الاقصر ما بلي : - م - اعتدال الطقس اغلب فترات العام .

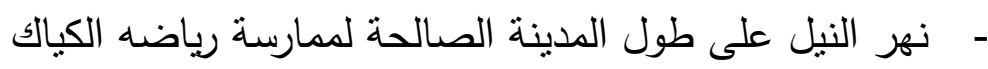

$$
\text { - }
$$

- - توفير الاعتمادات المالية للإعلان عن المناسبات الرياضية والتسويق الجيد

- ت توافر وسائل الإعلام و الاتصالات المختلفة مثل الأقمار الصناعية . - وجود المستثفيات القريبة من منشات السياحة الرياضية .

- وجود عربات الإسعاف المجهزة لنقل اللاعبين والسائحين المصابين ل

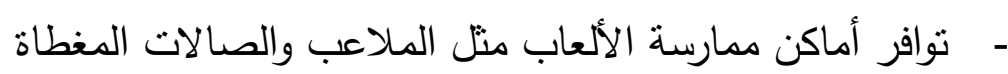
- توفير الاعتمادات المالية للإعلان عن المناسبات الرياضية والنسويق الجيد لها

- - توفير الاعتمادات المالية توفير أجهزة التدريب وأماكن صيانتها . - - توافر كوادر مؤهلة للعمل في مجال السياحة الرياضية .

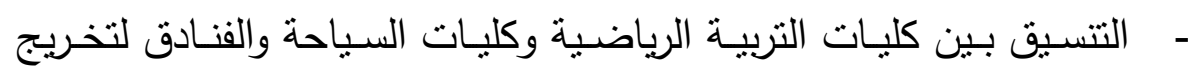
كوادر مؤهلة للعمل في مجال السياحة الرياضية .

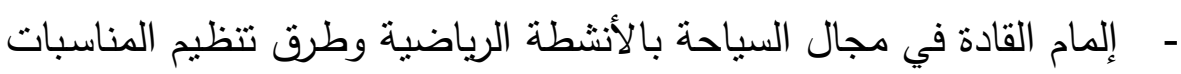


- إلمام القادة في مجال التربية الرياضية بالأنشطة السياحية وطرق جذب وتنشيط السياحة. - - إعـداد الكـوادر الرياضـية المتخصصــة فـي بـرامج التتشـيط والتسـويق والتخطيط لبرامج السياحة الرياضية .

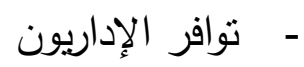
-

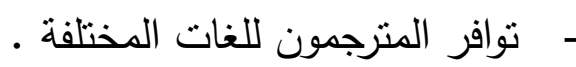

\section{المحمر الثشاثث}

\section{الإجراء|ت}

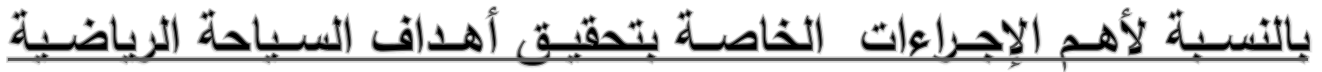
بمحاقظة الإقصر أظهرث الثتائج إلى أن أهم الإجراءات اللازمة لتحقيث أهداف للسبياحة

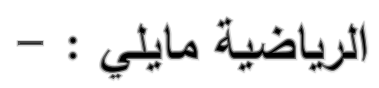

- وضـع خطة سنوية للنشاط السياحة الرياضية تتمثل في تتظيم مهرجانات

$$
\text { واحتفالات رياضية على مدار العام }
$$

- - الإعلان عن موارد السياحة الرياضية بالاقصر وإعداد الكتيبات والخرائط

$$
\text { السياحة }
$$

- العمل على تتوع المناسبات والمهرجانـات واختلافها وإقامتها على مدار

$$
\text { العام }
$$

- العــل على جذب الاسـتثمارات في مجـال السـياحة الرياضـية وإعـداد الإمكانات اللزمة لها 
- ت تتظيم حمـلات إعلانيـة عن موارد السياحة الرياضية بحافظـة الاقصر

حتى يتسنى لثركات السياحة المحلية والدولية إعداد البرامج السياحية

- توافر الخدمات المقدمة للسائحين والعمل على تتوعها واختلافها .

- الاهتمـام بالتدريب العملي والتعـاون بين كليات التربيـة الرياضية وكليات

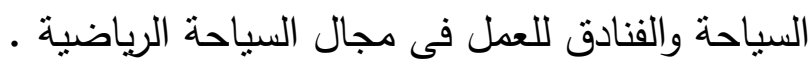

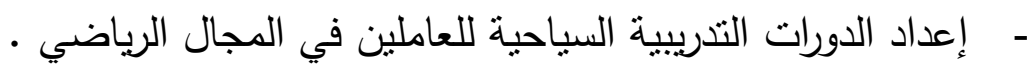

- إعداد الدورات التدربيية الرياضية للعاملين في المجال السياحي · ل

- الاستعانة بالخبراء العالميين في مجال السياحة الرياضية .

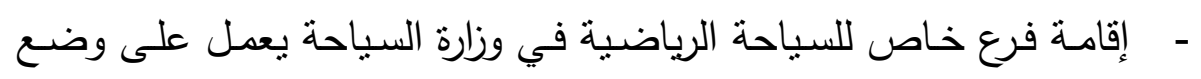
برامج السياحة الرياضية.

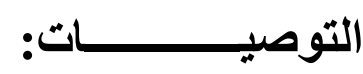

ضرورة الاستفادة من المقومات الطبيعية والمناخية المتوفرة بمحافظة الاقصر بغرض السياحة الرياضية ضرورة وضع خطة قومية للاستفادة من زيادة أعداد السائحين الو افدين إلى محافظة الاقصر الاستعانة بنتائج الأبحاث المرتبطة بمجال السياحة الرياضية

إقامة فرع خاص بالسياحة الرياضية بالمجلس القومي للرياضة لوضع بر امج السياحة الرياضية التنسيق بين الاتحادات الرياضية وكليات التربية الرياضية وكليات السياحة والفنادق لتخريج كو ادر مؤ هلة اللعمل فى مجال السياحة الرياضية

المراجع

ا .صبري احمد عبد السميع : نظرية السباحة، الطبعة الثانية، مطبعة الطوبجي،

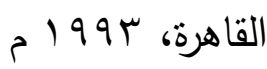


r. هباس رجائي الحربي : التسـويق السباحي في المنشـآت السياحية ، دار أسامة

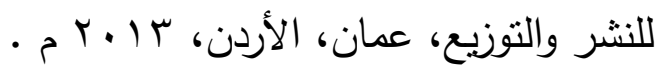

r. أبو بكر عوني على عطية :التخطبط لموارد السباحة الرياضبة ، دار الوفاء لدنيا الطباعة والنشر والتوزيع، الإسكندرية، 11 • ب م •

؛. حمدينو عمر السيد : دور السباحة الرياضبة في تنمبة الجذب السباحي لجمهورية مصر العربية، رسالة ماجستير منشوره، كلية التربية الرباضية جامعة المنصورة،

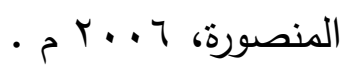

0. أثرف سمير الميداني ،ميرفت على خفاجة : دور السباحة الرياضبة في التنمية السبياحية، المؤتمر الاقليمى الرابع للمجلس الدولي للصحة والتربية البدنية والترويح والرياضة والتعبير الحركي لمنطقة الثرق الأوسط، كلية التربية الرياضية بنين، جامعة الإسكندرية، 1 . . . م م.

7. جمال محمد على، مؤمن عبد العزبز عبد الحميد، بسام صلاح محمد على : دراسة تقويمبة للسباحة الرياضبة في محافظات صعيد مصر، مؤنمر علوم الرياضة في قلب الربيع العربي ب، الغردقة، نوفمبر با ـ ب م •

V. أحمد نبيل كامل الثيخ (ع . . rم) : "دور السياحة الرياضية في تتمية الموارد بالاتحادات الرياضية بجمهورية مصر العربية" رسالة ماجسنير، كلية التربية

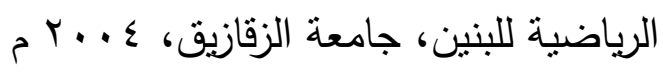

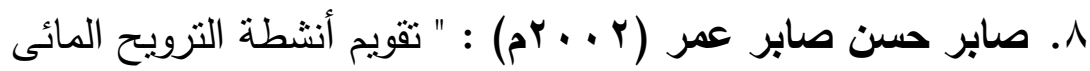
بالمشروعات السياحية فى مصر" ، رسالة ماجستير غير منشورة ، كلية التربية الرياضية للبنين بالهرم جامعة حلوان ، القاهرة 


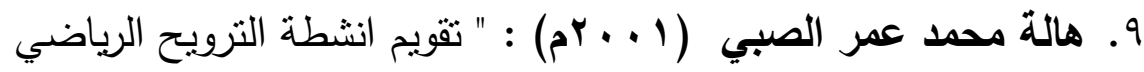

بالمشروعات السياحية في جمهورية مصر العربية" دكتوراه منشورة كلية التربية

الرياضية جامعة طنطا

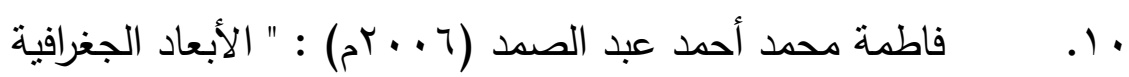

للسياحة العلاجية في مصر "سلسلة بحوث جغرافية ، العدد الخامس عشر ،

الجمعية الجغرافية المصرية، القاهرة

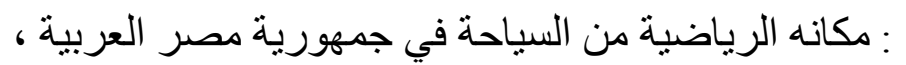

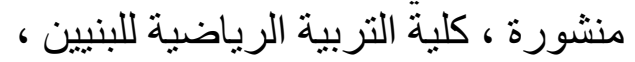

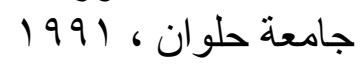

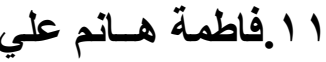

رسالة ماجستير غير

: تقوبم إمكانات السبيحة الترويحية الرياضية بدولة الكويت ، مجلة

r ا نليفة ابو طالب بهباتي

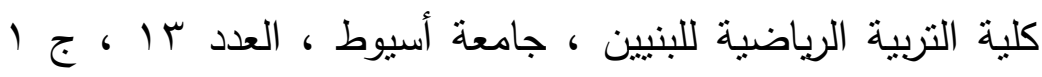

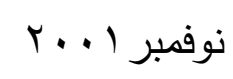

شبكه المعلومات الدولية:

http://www.arabiyat.com/torums/archive/index.php/t-6043/html$1 \mathrm{rgk}$

(11 